\title{
THE EFFECT OF USING SMALL GROUP DISCUSSION TECHNIQUE ON STUDENTS' SPEAKING SKILL AT XI GRADE OF MAS KEPENUHAN
}

\author{
Nur Elmi Hidayati ${ }^{1}$, Batdal Niati ${ }^{2}$ \\ English study program university of pasir pengaraian \\ Elmydayah@gmail.com,batdaln@gmail.com
}

\begin{abstract}
The purpose of this research was to find out the effect of Small Group Discussion technique on students' speaking skill in narrative text. This research was conducted in March 2019. The sample was the eleventh grade students of Madrasah Aliyah Swasta (MAS) Kepenuhan. The research method was Experimental research, the number of the sample joined in this research was 40 students. The researcher divided them into two classes, the research post-test only design to find out the effect of Small Group Discussion technique toward on students' speaking skill. According to the test given, the researcher found that the students' post test in the independent sample T-test was 0.000 smaller than 0.005 with probabilitas 2tailed, So, $0.000 / 2=0,000$ smaller than $\alpha=0.005$, or $0,000<0.05$. So. $\mathrm{H}_{\mathrm{O}}$ rejected. The df 38 . It could be concluded that $\mathrm{H}_{\mathrm{a}}$ accepted and $\mathrm{H}_{\mathrm{O}}$ rejected. It means small group discussion had significant effect on students speaking skill in the narrative text at Eleventh grade students of Mas Kepenuhan.
\end{abstract}

Keywords: True Experimental, Speaking, Small Group Discussion

\section{INTRODUCTION}

In the flourishing era languages very important such as like the English language because the English language is an international language used by each country. In Indonesia especially Rokan Hulu English is a foreign language that is rarely heard in daily communication. In English, there are several skills that must be mastered. According to Tarigan (2006:1), the ability in communication consists of four skill, they are listening, speaking, reading and writing skill. 
In Curriculum 2013 English is a compulsory subject especially in speaking skill, but in fact, there are many problems in the field. Base on the preliminary study conduct in January 2019 at Eleventh grade of MAS Kepenuhan about speaking. There are many factors influence their speaking Such as students lack in the vocabulary, students didn't have more confidence, students less motivation, teacher always teaches English not make students interesting in learning process.

Small Group Discussion is one of the techniques to teach speaking, because Small Group Discussion is an effective way since it will increase the amount of time for student's talk during the given period o time, Hadriana (2008: 37) its mean that Small Group Discussion is the technique to effective teaching in the class can solve the problem speaking students. The purpose of

the research is to improve students speaking skill using small group discussion technique.

\section{REVIEW OF RELATED THEORIES}

English has four skills such as listening, speaking, reading and writing. Speaking is one of the four skills as a tool to communicate with other people. Thorburry (2005: 1) states that speaking is a speech production that becomes a part of our daily activities. It means that speaking is the process of producing sound and constructing meaning from someone to another one and can give information and state what they want. Rahayu (2012 : 60 ) states that speaking is one way human beings make connections with each other and in ( Rahayu $2015: 62$ ).

Speaking is the important aspect of learning a language is mastering the art of speaking and success as measured in terms of the skill to carry out conversation in the language. According to Chastian ( in Sanusi 2010: 8) Speaking is a productive skill since it produces ideas, message or suggestion as a language learning to speak and need practice. It can say that speaking is interaction from one people to another people to covey their idea or their fill and speaking need always to practice to make a good speaker and speaker need a listener to listen or feedback their message. Speaking is the 
ability to make use of words or language to express oneself in an ordinary voice.

There are many definition of narrative text. In curriculum 2013 state that narrative text defined as text which function is to amuse, entertain, and to deal with actual or various experience in different ways. Narrative deals with problematic events lead to a crisis or turning point of some kind in turn finds a resolution. Andersone (1997: 8) states that narrative is a piece of text tell a story and in doing so, entertain or inform the reader or listener.

According to Doddy, Sugeng, Effendi (2008 : 23) Narrative text is the text to amuse, entertain and to deal with actual or various experience in different ways. The Narrative includes fairy stories, fables, mystery, stories, science fiction, romance, horror, etc. Base on the theory above the researcher concludes the definition of narrative is the text tells about the story to entertain the reader.

Small Group Discussions an effective technique when teaching students' speaking skills in the classroom, Antoni(2014). States that the implementation of Small Group
Discussion is a good variety of teaching techniques in the effort of improving student's speaking competency. Padilha (2006 : 156 ) states that Small Group Discussion is the patterns created in a group of a limited number, group discussion is a face to face activity, nonverbal behaviors such as gaze and gesture. Group discussion consists of a group of people more than two,that are together (e.g sitting around a table engaged in more or less informal talk about one or more topics. Kindsvatter (1996: 242) states that a Small Group Discussion dividing the large classroom into small groups of students to achieve specific objectives permits students to assume more responsibility for their own learning, develop social and leadership skills and become involved in alternativeinstructional approach. According to Dobson in Antoni (2014: 56) explains that discussion technique in Small Group Discussion are outlined as follows; first, divide the class into small group of three to six students each. Give each group different discussion topics that will necessitate outlining of several important points. Have one student in each group to 
write down these points as they emerge from discussion by the group member. Second, allow the group to discuss their respective topic for at least 10 minutes. When group member have finished their discussion, they should elect spokesman who will report on the group collective Small Group Discussion technique and in the control group no use treatment.

According to L.R Gay (2012:249) Experimental. research the researcher manipulated at least one independent variable, controls other relevant variables and observes the effect on one or more dependent variables and observes the effect on one or more dependent variables. The researcher chose one class as an experimental class where the students were given a treatment and after that students were given a post-test. Then control classes was only given a post-test. To find out the effect of using Small Group Discussion on students' speaking in narrative text, the researcher used speaking test. The test was a post-test that to find out the students' speaking skill in.

\section{FINDING AND DISCUSSION}

Based on the data, the research finding that was the positives effect (improvement) of students' speaking skill

Thought to the entire class. Last, call on the spokesman of one of the group. After he gives a short presentation ( five minutes or so ) class members should question him or anyone else in the group in viewpoint expressed. You can help the general discussion along by addressing your own question to member of the group.

\section{RESEARCH METHODOLOGY}

This research was conducted in a "True Experimental" post-test only control design. In this design, there were two groups taken randomly from certain populations. The experiment group used a narrative text after gave treatment by using Small Group Discussion technique. In this research, the researcher give a topic about narrative text. The students' speaking skill was assesed based on speaking components by hughes( $2003: 131)$.

In this research, the researcher used post-test only to collect the data. Firstly, the researcher gave a treatment. Secondly, In the experiment class and 
control class, the researcher gave a post-test with some topics. Thirdly, the students discussed the story and found the generic structure of the story, after the students discussed, students told the story. Fourthly, the researcher recorded the students' speaking in telling the story. Lastly, the data was scored by the raters and then the data was analyzed by the researcher. especially in narrative text in post test in the two groups; control group and experimental group

Table 5.The Data Description of Experimental and control group

\begin{tabular}{|l|c|c|c|c|c|}
\hline post test & $\mathrm{N}$ & $\begin{array}{c}\text { Minimu } \\
\mathrm{m}\end{array}$ & Maximum & Mean & $\begin{array}{c}\text { Std. } \\
\text { Deviation }\end{array}$ \\
\hline experiment & 20 & 43 & 69 & 57.90 & 8.265 \\
\hline post test control & 20 & 29 & 50 & 40.15 & 5.967 \\
\hline Valid N (listwise) & 20 & & & & \\
\hline
\end{tabular}

Table 5 showes the data describtion of experimental group and control group in post-test. It could be seen in post-test of experimental group, the total students was 20 , the minimum score was 43 , maximum was 69, mean was 57.90, standard devitiation was 8.265 and while post test score in control group, it can be seen the total students was 20, minimum was 29 , maximum was 50 , mean was 40.15 and standartd deviation was 5.967. from the data, the result between post-test experimental group and post-test control group were very different.

Table 10

Normality Test after treatment

\begin{tabular}{|l|c|c|c|c|}
\hline \multirow{2}{*}{ Teaching } & & \multicolumn{2}{|c|}{ Shapiro-Wilk } & \multirow{2}{*}{ Conclusion } \\
\cline { 2 - 5 } & $\mathrm{N}$ & Sig & Hypothesis & Normal \\
\hline Post-test experimental & 20 & 0.182 & $\mathrm{H}_{\mathrm{o}}$ Accepted & \\
\hline Post-test control & 20 & 0.448 & $\mathrm{H}_{\mathrm{o}}$ Accepted & Normal \\
\hline
\end{tabular}

Based on the table 10 above it showed the significance value on shapiro-wilk on learning outcomes data after experimental treatments in the group obtained $\mathrm{Sig}=0.182>\alpha=0.05$. post test in control group obtained sig $=0.448$. so, the hypothesis between 
class experimental and control class

after treatment was accepted and

normal

Table 11

Homogeneity Test after treatment

\begin{tabular}{|c|c|c|l|c|}
\hline Test of leven & A & Sig. F & hypothesis & Conclusion \\
\hline Based on Mean & 0,05 & 0.067 & $\mathrm{H}_{\mathrm{o}}$ Accepted & Homogenous \\
\hline
\end{tabular}

Based on the data above, we could see that sig $\mathrm{F}=0.067$ bigger than 0.05 or $0.067>0.05$. So, the data was accepted and the data homogenous. It mean from the data both of classes homogenous. Then to answer question from the hypothesis, the researcher takes a significant ( 2 tailed).

Table 12

T-Test in post test after Treatment

\begin{tabular}{|c|c|c|c|c|}
\hline Sig. (2-tailed) & A & Df & T tabel & Conclusion \\
\hline 0.000 & 0.05 & 38 & 2.021 & $\mathrm{H}_{\mathrm{a}}$ Accepted \\
& & & & $\mathrm{H}_{\mathrm{o}}$ Rejected \\
\hline
\end{tabular}

Based on the table 12 above, characteristic of the data hypothesis showed that if sig more than $\alpha$, So, $\mathrm{H}_{\mathrm{a}}$ Accepted. Based on the data above, we could seen that sig fo equal variances assumed sig.(2-tailed) with 0.000 with probabilitas 2tailed, So $0.000 / 2=$ 0,000 Smaller than $\alpha=0.05$, or 0,000 $<0.05$. Based on the research findings, there is a significant difference of students' post-test means score between the experimental and control class. The significant score in post-test in the independent sample T-test was 0.000 smaller than 0.005 it means that on the other word, the small group discussion had a significant effect on students speaking skill in the narrative text at eleventh grade students of Mas kepenuhan. Small group discussion is an effective technique when teaching students' speaking skill in the classroom. It was support with expert opinions.

Antoni( 2014) states that the implementation of small group discussion one good variety of teaching techniques in improving students' speaking competency. Dealing with the research finding, Ernest W.brewr ( 
1997) States that Small Group Discussion has the advantage the first, all participants in the group can participate, it means that all of member in the group can active in discussion, the second,It is a good way to get participants interested in a topic, the So. $\mathrm{H}_{\mathrm{O}}$ Rejected. The df 38. It could be concluded that $\mathrm{H}_{\mathrm{a}}$ accepted and $\mathrm{H}_{\mathrm{O}}$ rejected, which means there was a significant effect of using small group discussion on studentsspeaking skill in Narrative text at Eleventh grade of mas kepenuhan.

Third, It is increases participants interaction and socialization, the fourth, Participants may more easily understand another participant's explanation than a presenter's explanation. The fifth, The presenter can identify individual opinions about the topic. The sixth, It helps the participant see relationships among ideas or concepts related to the topic.

From this research the researcher found that the students can learn with used small group discussion with affective, students could to telling the story with confidence and they can share their idea with their friends to determine structure organization of the text with speaking skill and than the students could follow the study with good condition and their give good feedback. Small group discussion technique teach could improve students speaking ability.

\section{CONCLUSION AND SUGESTION}

Based on the reserch findings, it can be concluded that there is a significant effect of students'speaking skill in the narrative text of the eleventh grade students of the MAS Kepenuhan. . It caused after looking at tha result of the data calculation in previous chapter where Null Hypothesis $\left(\mathrm{H}_{\mathrm{O}}\right)$ was rejected, an alternative hypothesis $\left(\mathrm{H}_{\mathrm{a}}\right)$ was accepted, we can seen that T-test $=$ 0.000 smaller than $\alpha=0.05$. It means that on the other word, the small group discussion had significant effect on students speaking skill in the narrative text at Eleventh grade students of Mas Kepenuhan. a Small Group Discussion technique is recommended to be implemented as one of the techniques to teach speaking senior high school students. 


\section{REFERENCES}

Arikunto, Suharsimi. 2006. Prosedur Penelitian Suatu Pendidikan Praktik. Jakarta: Rineka Cipta.

Antoni,Rivi2014. Teaching Speaking Skill Through Small Group Discussion Technique At The Accounting Study Program. Journal of education and islami studies Vol 5,Num,1 January-June 2014.

Anderson, Mark. 1997. Text Type in English 2. Australia: Mackmillan.

Argawati, ningtias orilina. 2014.Improving Student's Speaking Skill Using Small Group Discussion(Experiment Study On The First Grade Students Of Senior High School).

Asril,Zainal.2010.Micro

Teaching.Jakarta: PT Raja grafindo.

Brown,H.Douglas.2004. Langage Assessment Principles And Classroom Practices. Longman : San Fransisco State University.

Brown ,H.Doughlas.1994.Teaching by principles an interactive Approach to language pedagogy. New York : Prentice Hall regents

Bygate ,M. 1997. speaking. New york : oxford universiy press

Carter ,Nunan 2001. The Cambridge Guide To Teaching English To Speakers of Other Languages.cambridge university press.

Gillies,Ashman,Terwel.2008. The Teacher's Role In Implementing Cooperative Learning In The Classroom.

Gay, L.R. 1987. Educational Research: Competencies for
Analysis and Application. Ohio: Merill Publishing Company.

Harris, David. P. 1969. Teaching English As a Second Language. New York: Mc. Graw- Hill Book Company.

Harmer,jeremy.2001. the practice of english language teaching. Englad: pearson education limited.

Hastoyo, Sovenda Septa. 2010. Improving Students' Speaking Competence through Small Group Discussion. Solo: ThesisUnpublished.

Hadriana.2009. Improving Student's Speaking Skill Through Communicative Activities In Small Group Discussion At The Tird Semester Class A Of The English Study Program Of Fkip Unri.

Jollife,Wendy.2007.Cooperative Learning In The Classroom Putting It Into Practice.

Nunan, David.2005. Practical english langage teaching young learner

Nazir,Moh.2003. Metode Penelitian.Jakarta ： Galia Indonesia

Nunan, D. 2003. Practical English Language Teaching. New York: McGraw-Hill

Neo, Ernest. 2005. Narrative for ' $O$ ' Level. Malaysia: Longman.

Naqsabandi,Rahmad.2015. The Effectiveness Of Using Small Group Intruction In Teaching Speaking At Smpn 5 Kedungwaru

Paul,routledge.2003. Teaching English As Foreing Language.prancis. Taylor \& prancis library. 
Padilha,Emiliano

Gomes.2006.Modelling Turn-

Taking In A Small Group

Discussion.University

Of

Edinburgh.

Prastowo, Andi.2010.menguasai teknikteknik koleksi data penelitian kuantitatif.Jogjakarta : Diva press.

Rianto,Honang.2015. Improving Speaking Skill Through Small Group Discussion( A Class Action Research For The Third Grade Students Of Vocational Secondary School Pancasila Salatiga In The Academic Year 2015/2016.

Sugiyono,2015. Metode Penelitian Pendidikan Pendekatan Kuantitatif,Kualitatif Dan R\& D. Bandung: Alfabeta

Soemanto, wasty.2009. Pedoman Teknik Penulisan Skripsi ( Karya Ilmiah).Jakarta: Bumi Aksara.

Sundayana, Rostina.2010.Statistika Penelitian Pendidikan.Garut : Stikip Garut Pres.

Sumantiah. 2015. Small Group Discussion In Teaching Speaking At Eleventh Grade of Senior Hight School 3 Malang.

Surgenol,Paul.Teaching Toolkit. Speaking And Listening Resource Book. Departement of education. 2013.

Sudjana, Nana. 2007. Penelitian dan Penilaian Pendidikan. Bandung: Sinar Baru Algensindo

Thornbury,s.2005.How to teach speaking. New York: persn Education Inc.

Ur, P. 2000.A Course In Language Teaching Practice And
Theory.London: Cambridge Univesity Press.

Brewer.Ernest.1997. 13 Proven Ways To Get Your Massage Across The Essential Reference For Teacher, Trainers, Presenters And Speaker.Corwin Press.

Sudjana, Nana. 2007. Penelitian dan Penilaian Pendidikan. Bandung: Sinar Baru Algensindo

Thornbury,s.2005.How to teach speaking. New York: persn Education Inc.

Ur, P. 2000.A Course In Language Teaching Practice And Theory.London: Cambridge Univesity Press.

W.Brewer.Ernest.1997. 13 Proven Ways To 